Ann. Biol. anim. Bioch. Biophys., 1978, 18 (1), 69-80.

\title{
Hormonal regulation of calcium metabolism in the newborn
}

par J.-P. BARLET, J.-M. GAREL *

Laboratoire des Maladies métaboliques, I.N.R.A.

Theix, Saint-Genès-Champanelle, 63110 Beaumont

* Physiologie du Développement, Université Pierre et Marie Curie, 9, quai Saint-Bernard, 75230 Paris Cedex 05.

Summary. The parathyroid status at birth is species-dependent. In some species, it has been suggested that in utero, high plasma calcium levels inhibit the parathyroid function before birth, but other unknown factors may be involved in this suppression. The maturity of the renal cortex adenyl-cyclase activity in the early postnatal period is also species-dependent, and the degree of renal immaturity is not sufficient to explain the postnatal increase in plasma phosphates.

Three factors are involved in the hormonal regulation of calcium homeostasis: parathyroid hormone (PTH), calcitonin (CT) and vitamin $D_{3}$ metabolites. Calcium metabolism is also intimately interrelated with phosphorus and magnesium. In this review, neonatal calcium physiology will be discussed by examining each hormonal factor.

It is well known that hypocalcemia occurs in human neonates, but strangely enough, it is unreported in animals. It has been postulated that hyperphosphatemia per se, transient hypoparathyroidism and/or end-organ unresponsiveness might explain the early postnatal decrease in plasma calcium. Craig and Buchanan (1958) stated that hypocalcemic tetany per se occurring within $36 \mathrm{~h}$ after birth in human neonates should be regarded as an exaggeration of a normal physiological state. The studies of plasma calcium levels in maternal and fetal blood (Bawden, Wolkoff and Flowers, 1965 ; David and Anast, 1974 ; Delivoria-Papadopoulos ef al., 1967 ; Radde, Parkinson and Hoffken, 1971) suggested the presence of active transport across the placenta. The sudden cessation of this source of calcium may contribute to the development of neonatal hypocalcemia. In the first two days of extra-uterine life, the serum calcium in full-term newborns decreases to levels between 8 and $9 \mathrm{mg} / 100 \mathrm{ml}$. A more pronounced postnatal decrease of the serum calcium is defined as pathological neonatal hypocalcemia.

\section{Plasma concentrations of calcium, phosphate and magnesium.}

In the cord blood of the human newborn, elevated levels of total and ionized plasma calcium have been observed (David and Anast, 1974). During the first $48 \mathrm{hrs}$ of life there was a decrease in total and ionized plasma calcium, followed 48 hrs later 
by a parallel increase of both (David and Anast, 1974). Plasma magnesium and phosphate levels increase progressively after birth in normal infants (David and Anast, 1974). Unfed newborn rats delivered by cesarean section show a sharp decrease in plasma concentrations of calcium and inorganic phosphorus within 6 hrs after birth (fig. 1). Suckling newborn rats had low plasma concentrations of calcium and inorganic phosphorus 12 hrs after birth, but reached stabilized levels 36 hrs after birth (Garel and Barlet, 1976). A slight decrease in plasma magnesium level was observed in newborn rats delivered by cesarean section ; 12-hour old suckling newborns exhibifed an increase in plasma magnesium level, and over the first week of life this level remained stable (fig. 1).

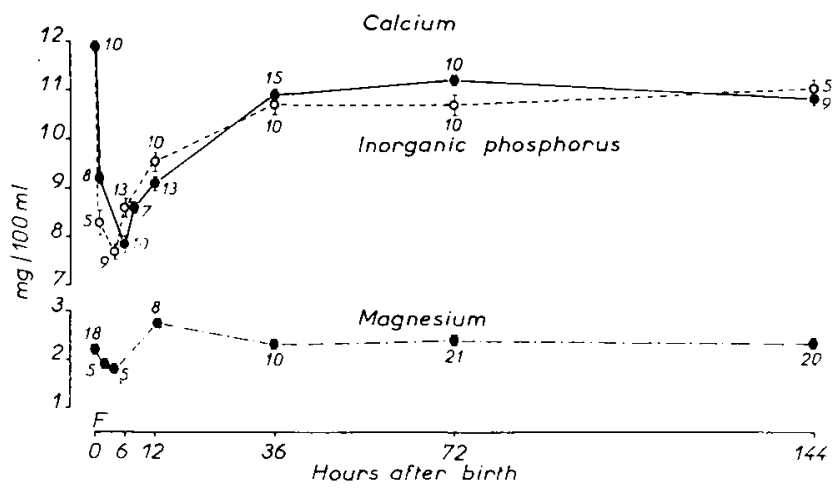

FIG. 1. Plasma concentrations of calcium, inorganic phosphorus and magnesium in newborn rats over the first week of life. Two groups of newborn rats were used : fasted newborns delivered by cesarean section studied with $8 \mathrm{hr}$ after birth, and suckling newborns naturally delivered. The latter were studied from 12-144 hr after birth. F indicates fetal plasma values obtained before cesarean section. The results are expressed as means $\perp$ SEM and the integer represents the number of animals.

(From Garel and Barlet, 1976.)

At birth, the plasma calcium level was higher in newborn foals than in their dams (fig. 2) ; a slight hypocalcemia occurred in the 48 hrs after birth. Plasma phosphate concentration increased sharply over the first week of life; however, plasma magnesium level in newborn foals did not change over that same period (fig. 2 ). A twofold increase in plasma phosphate occurred between $0 \mathrm{~h}$ and 3 weeks after birth in the lamb, and a small but significant increase was also observed in plasma calcium concentration (Garel and Barlet, 1976). A significant increase in plasma magnesium level was observed in lambs 24 hrs after birth, but this level declined 1 day later. In newborn calves, plasma calcium level increased befween 0 and 2.5 days after birth and then decreased significantly on day 5 (fig. 3). The plasma phosphate concentration also increased after birth (fig. 3). In 8 kids, plasma calcium and magnesium levels remained stable during the first 6 days of life, whereas plasma phosphate increased from $2 \mathrm{mg} / 100 \mathrm{ml}$ during the same period (Barlet et al., 1971).

The postnatal increase in plasma inorganic phosphorus is a general pattern. Some authors attributed this elevation to a low renal excretion of phosphates during the postnatal period (a possible result of transient hypoparathyroidism) and/or to the end-organ unresponsiveness to PTH. In sheep fetuses near term, the tubular reab- 


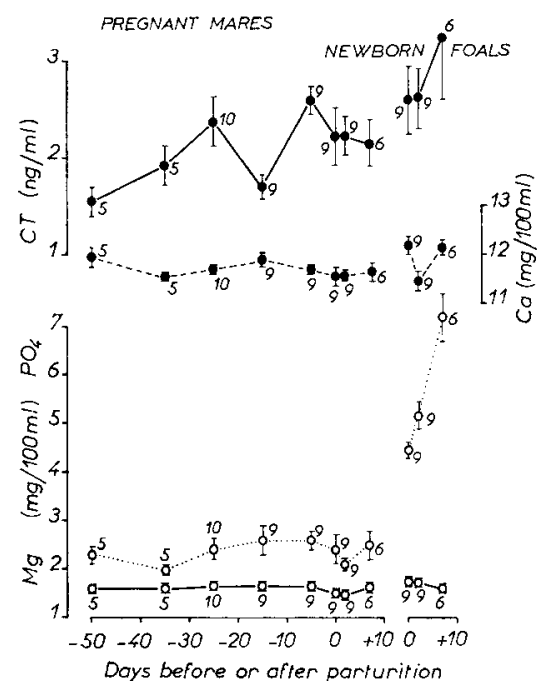

FIG. 2.

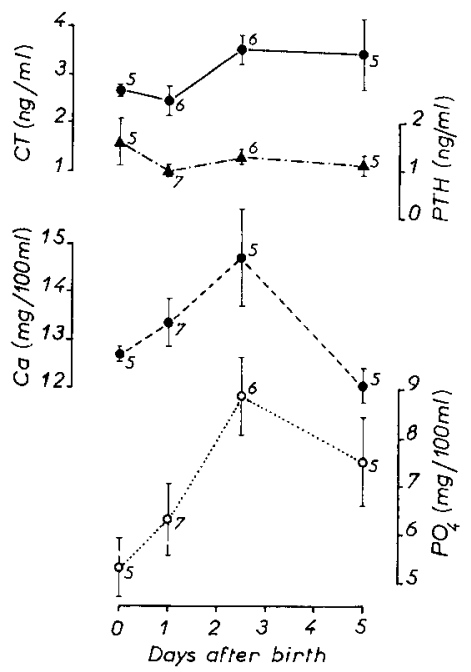

FIG. 3.

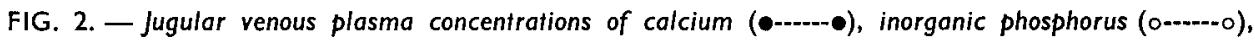
magnesium (०—o) and calcitonin (०——) in pregnant mares and their newborn foals. Means \pm SEM and the integer indicates the number of estimations.

(From Garel and Barlet, 1976.)

FIG. 3. - jugular venous plasma concentrations of calcium, inorganic phosphorus $\left(\mathrm{PO}_{4}\right)$, calcitonin (CT) and parathyroid hormone (PTH) in newborn calves. Means \pm SEM and the integer indicates the number of estimations.

(From Garel and Barlet, 1976.)

sorption of phosphates (TRP) is high, but parathyroid extract injection decreases the TRP and increases phosphate clearance (Alexander and Nixon, 1969 ; Smith et al., 1969). EDTA infusion in sheep fetuses, increasing the plasma immunoreactive PTH level, stimulated phosphate clearance (Smith ef al., 1972). These results indicate that renal cortex adenyl cyclase responds to PTH in utero in sheep fetuses near term. In vitro experiments have shown that adenyl cyclase of renal cortex homogenates from 27-day to term rabbit fetuses is stimulated to the same extent as adult extracts by PTH (Linarelli, Bobik and Bobik, 1973). In rats, basal renal adenyl cyclase activity was highest on the third day after birth and then declined to very low levels from the fifth day; parathyroid hormone markedly stimulated the homogenate adenyl cyclase activity from 1 to 5 days after birth (Gengler and Forte, 1972).

Phosphaturia is low in human newborns but increases on the third day of life. The increase in phosphate clearance and phosphaturia induced by PTH injection into these newborns is higher on the third day than on the first day (Conelly, Crawford and Watson, 1962). Basal and PTH-stimulated cyclic AMP excreted in the urine is higher on the third than on the first day (Linarelli, 1972).

The association of hypocalcemia (shifts in total and ionized calcium) and hyperphosphatemia in the human newborn have suggested the existence of a transient hypoparathyroidism ; this concept had been developed by many authors. This was substan- 
tiated by the observation of low or undetectable plasma PTH levels in human newborns (David and Anast, 1974), concomitant with a relative end-organ unresponsiveness to PTH.

Indeed, there is considerable species variation in the maturity of the renal cortex adenyl cyclase system at birth, even if the postnatal plasma phosphate always increases. Thus, end-organ unresponsiveness or immaturity of the renal receptor cannot be explained by the high plasma phosphate levels after birth.

\section{Vitamin D.}

Vitamin $D_{3}$ or cholecalciferol, produced in the skin or ingested, is converted to 25-hydroxycholecalciferol $\left(25-\mathrm{OHD}_{3}\right)$ in the liver and further hydroxylated on carbon 1 by the kidneys to form 1,25-dihydroxycholecalciferol, the active metabolite of vitamin $\mathrm{D}\left(1,25(\mathrm{OH})_{2} \mathrm{D}_{3}\right)$. Renal $1 \alpha$-hydroxylase is stimulated by PTH, low plasma phosphate concentration or low plasma calcium concentration. $1,25(\mathrm{OH})_{2} \mathrm{D}_{3}$ has been shown to increase intestinal calcium absorption and bone mobilization.

In human newborns, a highly significant correlation was observed in $25-\mathrm{OHD}_{3}$ concentrations in mother's serum and in mixed arterial-venous cord serum (Hillman and Haddad, 1974). These data are consistent with passive or facilitated placental transfer of $25-\mathrm{OHD}_{3}$. It was previously reported in pregnant rats that vitamin $\mathrm{D}_{3}$ and $25-\mathrm{OHD}_{3}$ were transferred across the placenta (Haddad, Boisseau and Avioli, 1971). Mendelsohn and Haddad (1975) have shown that plasma $25-\mathrm{OHD}_{3}$ levels decrease in 12-days old suckling rats, but that 24-day old weanling animals restore circulating $25-\mathrm{OHD}_{3}$ levels comparable to those at birth. The observed decrease in neonatal plasma $25-\mathrm{OHD}_{3}$ is consistent with insufficient vitamin $\mathrm{D}_{3}$ in milk, impaired hepatic production, and/or increased neonatal utilization. However, 3-day old newborn rats are able to convert vitamin $D_{3}$ to its 25 -hydroxylated metabolite, and the rate of $25-\mathrm{OHD}_{3}$ clearance from plasma is similar in the early and late suckling stages (Mendelsohn and Haddad, 1975). Injection of radiolabelled vitamin $D_{3}$ in 2-day old newborn rats resulted in the formation of $25-\mathrm{OHD}_{3}$ and 24,25-dihydroxycholecalciferol $\left(24,25(\mathrm{OH})_{2} \mathrm{D}_{3}\right) ; 1,25(\mathrm{OH})_{2} \mathrm{D}_{3}$ was not detected (Weisman ef al., 1976). When kidney homogenates of newborn rats were tested for their ability to hydroxylate 25-OHD 3 , a marked 24-hydroxylase activity was noted (Weisman ef al., 1976). The observed presence of relatively high levels of $24,25(\mathrm{OH})_{2} \mathrm{D}_{3}$ in newborn tissues and the high renal 24-hydroxylase activity may indicate a possible biological role for this metabolite (or a further one) in neonatal life. The high level of this metabolite in the suckling newborn rat is in agreement with a high plasma phosphate concentration (Garel, 1969a ; Garel and Barlet, 1976) and a high plasma CT level (Garel and Jullienne, 1977). In lambs studied at birth, mean plasma $25-\mathrm{OHD}_{3}$ before suckling is 98 p. 100 of maternal levels, and a highly significant relationship was found between fetal and maternal plasma 25- $\mathrm{OHD}_{3}$ (Ross et al., 1976) ; following birth, plasma 25$\mathrm{OHD}_{3}$ in lambs depends upon initial birth levels. Seasonal variation of $25-\mathrm{OHD}_{3}$, related to the sunlight, has been observed in the cord blood of human newborns (Frederich et al., 1976).

The two metabolites of vitamin $\mathrm{D}_{3}\left(25-\mathrm{OHD}_{3}\right.$ and $\left.1,25(\mathrm{OH})_{2} \mathrm{D}_{3}\right)$ are potent stimulators of bone resorption in newborn mice in vitro or in vivo, whereas vitamin $D_{3}$ 
itself is inactive (Reynolds, Holick and De Luca, 1973), and $1,25(\mathrm{OH})_{2} \mathrm{D}_{3}$ is about 100 times more potent than $25-\mathrm{OHD}_{3}$. Using epithelial cells from fetal rat intestinal tissue, Vegt and De Ruijter (1977) have shown that $1,25(\mathrm{OH})_{2} \mathrm{D}_{3}$ increases the uptake of calcium. According to Peshin, Ornoy and Menczel (1976), intestinal calcium-binding protein was already present in term rat fetuses. Intestinal calcium-binding protein is not produced before hatching in the chick embryo (Corradino, Taylor and Wasserman, 1969 ; Moriuchi and De Luca, 1974) and renal enzyme (1 $\alpha$-hydroxylase) activity reached a maximum on the day of hatching (Bishop and Norman, 1975). The intravenous injection of $1 \alpha$-hydroxycholecalciferol (synthetic analog to $\left.1,25(\mathrm{OH})_{2} D_{3}\right)$ in newborn foals $(1 \mu \mathrm{g} / \mathrm{kg}$ body weight) induced a significant and longlasting rise in total and ionized plasma calcium and plasma inorganic phosphorus levels (Barlet and Martin-Rosset, unpublished results) (fig. 4).

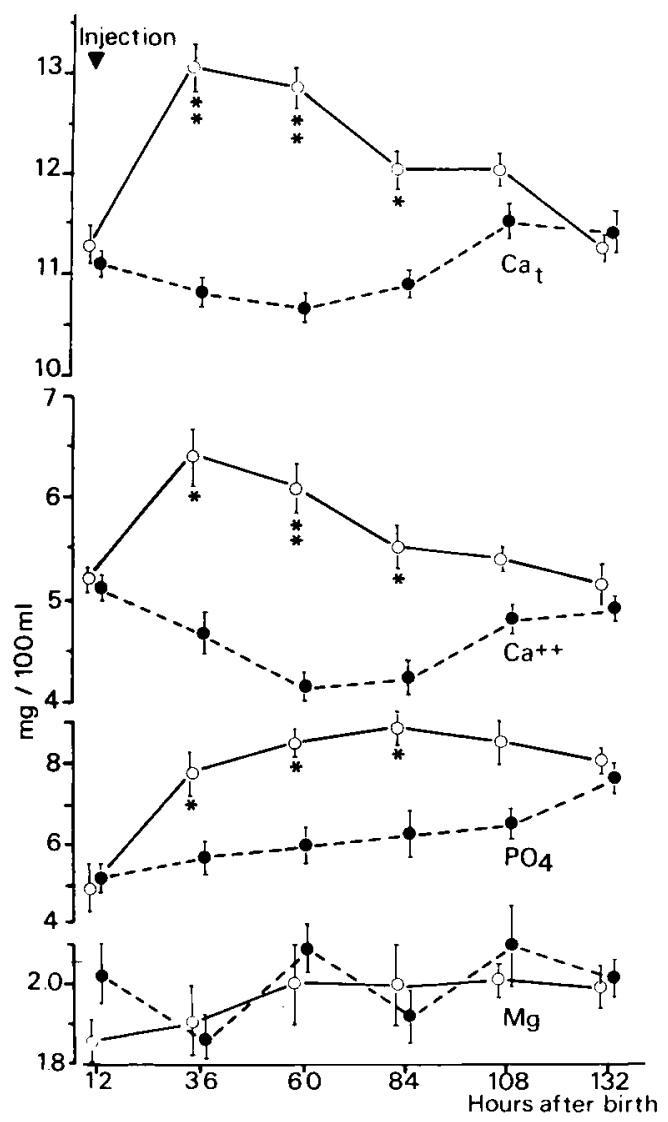

FIG. 4. - The influence of an intrevenous injection of $1 \alpha$-hydroxycholecalciferol $(1 \alpha$-OHCC) in newborn foals. $1 \alpha$-OHCC was given $12 \mathrm{~h}$ after birth in 4 animals (full line). The 4 controls (dotted line) received in the same way the same volume of solvant (propyleneglycol: $0.01 \mathrm{ml} / \mathrm{kg}$ body weight). Total plasma calcium (Cat) and magnesium $(\mathrm{Mg})$ were measured by atomic absorption spectrophotometry, ionized calcium $\left(\mathrm{Ca}^{++}\right)$was measured in whole blood using a calcium electrode (Orion SS-20) and plasma inorganic phosphorus $\left(\mathrm{PO}_{4}\right)$ was measured colorimetrically. Mean $\pm S E M ; * P<0.55 ; * * P<0.01$ (treated vs control animals). 


\section{Parathyroid hormone.}

PTH plasma levels similar to those found in adults are observed in newborn calves soon after birth (fig. 3) (Garel and Barlet, 1976 ; Barlet et al., 1976), indicating that parathyroid function in this species is not depressed at birth. The parathyroid status in calves and Rhesus monkeys during the early postnatal period seems to be similar since the latter have been shown to exhibit detectable levels of PTH within 24h after birth (Fleischman ef al., 1975). In the majority of normal human newborns,

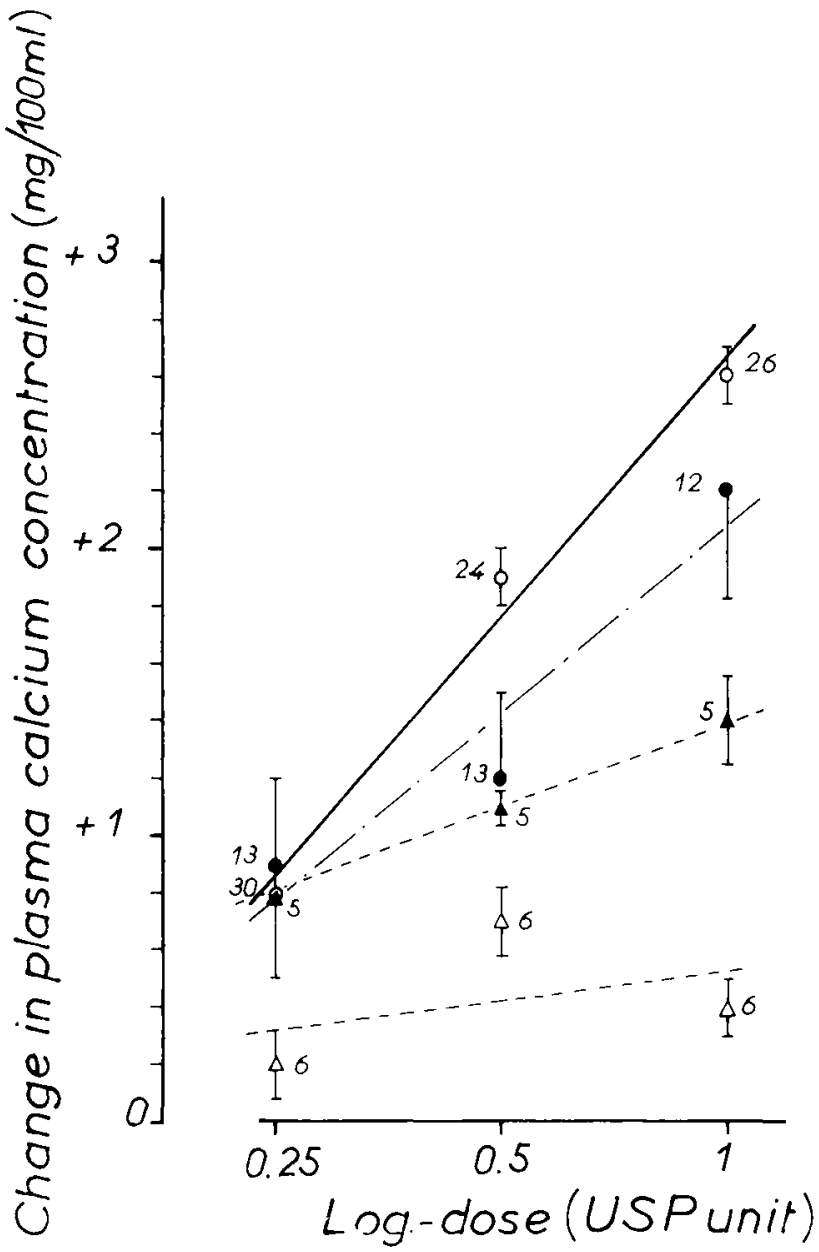

FIG. 5. - Effects of parathyroid extract (PTE ; total dose/animal) on plasma calcium concentration in 3-day old newborn rats, $4 \mathrm{~h}$ after s.c. injection. Each point indicates a mean value, the vertical bars indicate $\pm S E M$; the numbers indicate the number of animals. $\circ$ PTE alone injected into suckling newborn rats ; - - - PTE alone, newborn rats fasted for $7 \mathrm{~h} ; \mathbf{4}$ - - - 4 PTE +1 MRC mu, porcine calcitonin $(\mathrm{P}-\mathrm{CT}) / \mathrm{g}$, suckling newborn rats ; $\Delta-\cdots \Delta \mathrm{PTE}+8$ $M R C$ mu $P / C T / g$, suckling newborn rats. 
however, serum immunoreactive PTH levels are undetectable or low during the first $48 \mathrm{~h}$ of life (David and Anast, 1974), and 6-hour old Rhesus monkey newborns respond normally to EDTA-induced hypocalcemia by an increase in plasma PTH levels (Fleischman ef al., 1975). In full-term infants, citrate-induced hypocalcemia during « exchange » blood transfusions results in an increase in plasma PTH levels (Milner and Woodhead, 1975 ; Tsang et al., 1973a).

It has been proposed that end-organ unresponsiveness to PTH may occur in the neonate. However, calcemic response to PTH can be elicited from newborn rats (Garel, 1969b ; Garel and Barlet, 1974) (fig. 5), premature human infants (Tsang et al., 1973b), infants from diabetic mothers (Tsang et al., 1972), and infants with birth asphyxia (Tsang ef al., 1974). The phosphaturic response to PTH in the newborn has been discussed above (see first paragraph).

The spectrum of transient hypoparathyroidism is observed only in some species (human and perhaps horse) since neonatal hypocalcemia is very uncommon in animals. In horses the postnatal decrease in plasma calcium is very small and since the plasma PTH levels have not yet been measured, the existence of neonatal hypoparathyroidism remains speculative. In newborn lambs and newborn calves, the postnatal increase in plasma phosphates was not associated with a decrease in plasma calcium, whereas in rats the developmental changes of these two parameters were parallel after birth. In newborn calves, the plasma PTH levels were similar to those found in adults.

\section{Calcitonin.}

Our group was one of the first to report high plasma CT levels in the newborn (Garel ef al., 1973). Plasma CT levels are generally higher in newborns such as lambs (Garel, Care and Barlet, 1974), foals (Garel, Martin-Rosset and Barlet, 1975), calves (Barlet et al., 1976) and rats (Garel and Jullienne, 1977) than in the dams or adults. High CT levels were also reported in human newborns (Hesch et al., 1973 ; Samaan, Anderson and Adam-Mayne, 1975). Factors which control the high plasma CT level in the newborn are still poorly understood.

In 15-day old calves, the lack of hypocalcemic response following the intravenous infusion of purified porcine CT (Barlet, 1968) or the hypercalcemic perfusion of the thyroid gland isolated in sifu (Phillippo, Care and Hinde, 1969) has already been reported. This might be due to some particularities in the parameters of calcium metabolism in young calves (Larvor and Barlet, 1968). The measurement of the CT secretion rate in very young calves revealed a relatively low level of secretion $(100-200 \mu \mathrm{U} / \mathrm{min} / \mathrm{kg}$ body weight) at a perfusion calcium concentration of $8.5 \mathrm{mEq} / \mathrm{l}$, while it was $700 \mu \mathrm{U} / \mathrm{min} / \mathrm{kg}$ body weight in piglets 2-11 day old (Phillippo, Care and Hinde, 1969). Nevertheless, in three 10-day old thyroidectomized Jersey calves supplemented with thyroxine, the decrease in plasma calcium following an intravenous calcium infusion was significantly slower than in intact control animals (Barlet, unpublished results) (fig. 6). Similarly, the thyroid of the fasted newborn rat was able to secret CT in response to the calcium stimulus, since a calcium load given subcutaneously and increasing calcemia induced a significant rise in plasma CT concentration 30 min later (Garel 


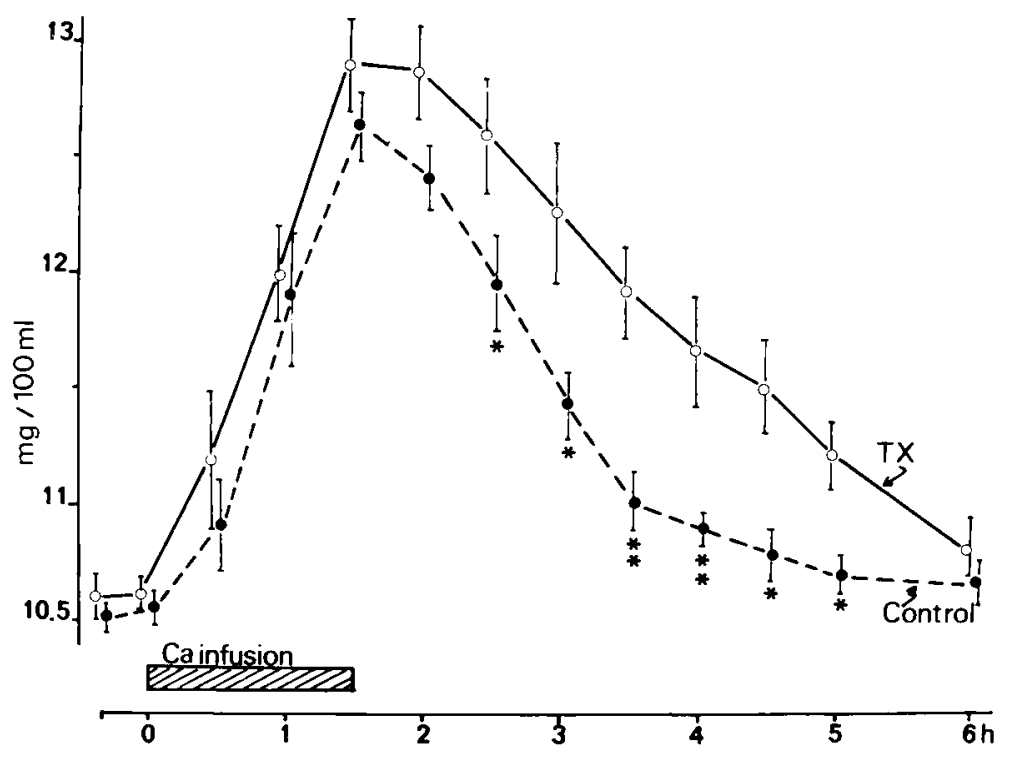

FIG. 6. - The influence of calcitonin (CT) deficiency on the hypercalcemia induced by calcium intravenous infusion in calves. CT deficiency was induced by thyroidectomy performed at least $48 \mathrm{~h}$ before Ca infusion. Thyroidectomized (TX) animals were daily supplemented with thyroxine $(10 \mu \mathrm{g} / \mathrm{kg}$ body weight). Ca glutamate was infused at the rate of $5 \mathrm{mg} \mathrm{Ca} / \mathrm{kg}$ body weight. Three 10-day old male Jersey calves were used in each group (mean $\pm \mathrm{SEM}$ ) $* \mathbf{P}<0.05 ; * * \mathrm{P}<0.01$ (thyroidectomized vs control animals).

and Jullienne, 1977). It has also been shown that calcium given orally $(10 \mathrm{mg} \mathrm{Ca} / \mathrm{kg}$ body weight) in the 1-hour old fasted newborn lamb did not change the plasma calcium concentration but increased plasma CT 1 h later (Barlet ef al., 1974) (fig. 7).

Garel, Barlet and Kervran (1975) have shown that CT decreased plasma triglyceride levels in suckling newborn rats mainly by inhibiting gastric emptying. If was also observed that a physiological dose of CT inhibited the elevation of plasma concentrations of total lipids, amino acids and glucose occurring after suckling in newborn lambs. These data suggested that $C T$ in suckling newborns was involved in the regulation of nutrient absorption and that a regulation loop could exist. Plasma CT levels in early newborn rats were always higher in suckling than in fasted animals (Garel and Jullienne, 1977), indicating that maternal milk was probably the cause of CT secretion. It is of interest that Frankel and Yasumura (1970) found that the CT content of rat thyroid measured by bioassay did not change significantly with age after 30 days, although suckling animals had markedly lower thyroid CT contents. In suckling newborn rats, the plasma CT concentration was always significantly higher than the levels found in virgin female rats (Garel and Jullienne, 1977). Rat milk is rich in triglycerides; since exogenous $C T$ decreased plasma triglycerides in suckling newborn rats, soybean oil was used as a CT secretagogue. The triglyceride composition of the soybean oil resembles the triglyceride composition of rat milk. One hour after administration of soybean oil by force-feeding, the plasma CT level was significantly increased in the 2-hour old newborn rat (Garel and Jullienne, 1977). In a 


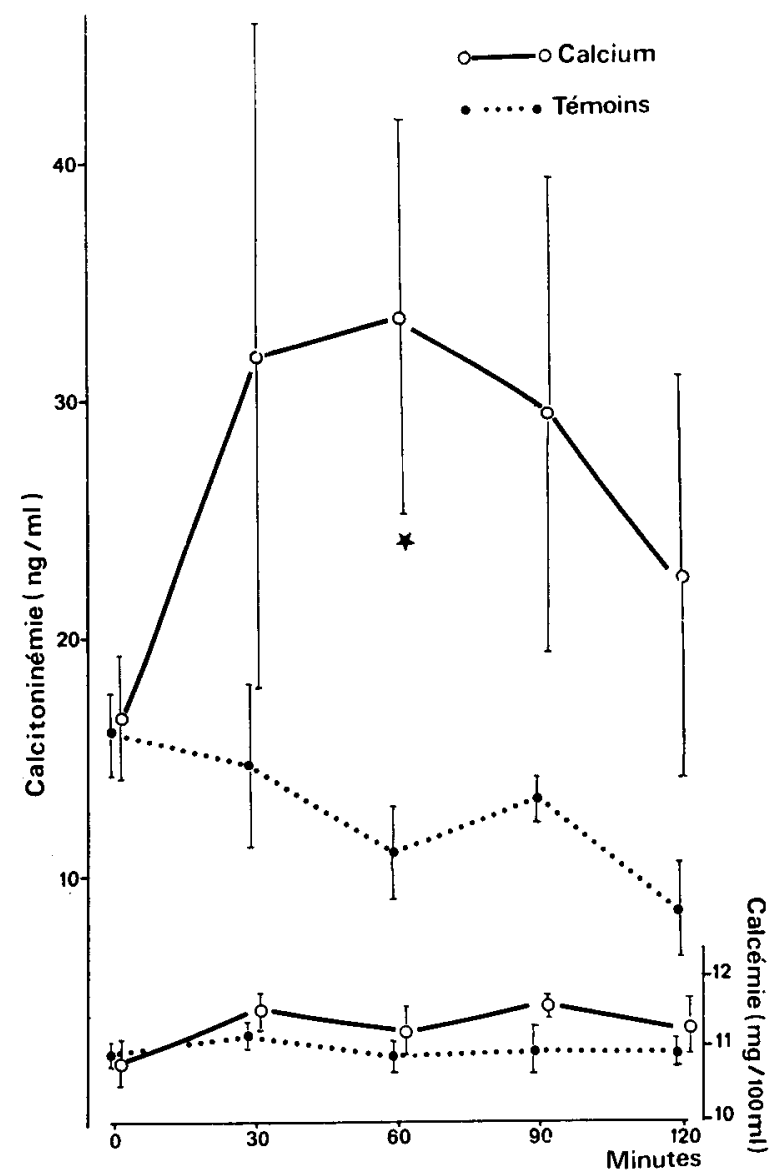

FIG. 7. - The effects on plasma calcium and plasma CT levels of a calcium load $(10 \mathrm{mg} / \mathrm{kg}$ body weight as calcium chloride) given orally to newborn lambs. Each point indicates a mean value, the vertical bars $\pm S E M$. Significance of difference between the two groups was tested by Students test. $* P<0.05 ; o=$ calcium ; $\bullet=$ control.

(From Barlet et al., 1974).

30-kg pig, the administration of intraduodenal fat was shown to stimulate CT secretion $1 \mathrm{~h}$ later (Swaminathan ef al., 1973). However, gastric distension alone is capable of stimulating not only gastrin secretion but also CT secretion (Swaminathan ef al., 1973). In 2-hour old fasted newborn rats, gastric distension remained without effect on $\mathrm{CT}$ secretion since force-feeding $0.9 \mathrm{p} .100 \mathrm{NaCl}$ in control animals did not change the plasma CT concentration (Garel and Jullienne, 1977).

It was noteworthy that pentagastrin, a potent $C T$ secretagogue in adults, did not stimulate $C T$ secretion in 2-hour old fasted newborn rats, even after injection of a pharmacological dose $(10 \mu \mathrm{g})$ (Garel and Jullienne, 1977). Similar results were already reported in early newborn lambs receiving gastrin $(2 \mu \mathrm{g} / \mathrm{kg})$ by intravenous injection (Barlet ef al., 1974). Endogenous cholecystokinin-pancreozymin (CCK-PZ) release is 
stimulated by the introduction of fat directly into the duodenum through a tube passed into the duodenum and tied round the pyloric sphincter (Young ef al., 1969) ; Care et al. (1971) showed that CCK-PZ was a potent stimulator of CT secretion in the thyroid gland of the pig perfused in vivo. In suckling newborn animals, the release of CCKPZ might be stimulated as in adults by a lipid-rich diet such as colostrum and milk. It is pertinent to note that CCK-PZ injection in 0 -hour old fasted newborn lambs induced a rise in plasma CT concentration associated with a drop in plasma calcium and phosphate concentrations, demonstrating an increase in CT release (Barlet and Garel, 1976). Glucagon was also ineffective on plasma CT in the 2-hour old fasted newborn rat (Garel and Jullienne, 1977). Soybean oil ingested by fasted newborn rats did not increase plasma immunoreactive pancreatic glucagon (Girard, Ferre and Pegorier, 1976). Thus, in suckling newborns, CCK-PZ might be one of the most important CT secretagogues. However, in view of the structural similarity between pancreatic glucagon (a recognized CT secretagogue in adults) and gastric inhibitory peptide, and the probability that the secretion of this peptide is stimulated by the ingestion of fat, it may be that gastric inhibitory peptide exerts some activity as a CT secretagogue in suckling newborns.

Réunion Groupe Développement INRA/Productions animales Montpellier, 17-18 mai 1977.

Résumé. Chez le nouveau-né comme chez l'adulte, le contrôle endocrinien de la calcémie est assuré par l'hormone parathyroïdienne, la calcitonine et le 1,25 dihydroxycholécalciférol.

Le fonctionnement parathyroïdien à la naissance semble variable selon les espèces. Chez quelques-unes, certains auteurs ont suggéré que les taux élevés de calcium sanguin mesurés chez les fœtus pourraient inhiber les parathyroïdes avant la naissance. II semble que d'autres facteurs, encore inconnus actuellement, puissent intervenir dans cette inhibition. La maturité du système adényl-cyclase du cortex rénal dans la période néonatale varie également selon l'espèce considérée. Cependant cette variation ne peut suffire pour expliquer à elle seule. L'élévation de la phosphatémie observée dans les jours suivant la naissance.

Outre son effet hypocalcémiant, la calcitonie semble jouer un rôle physiologique particulièrement important chez le nouveau-né en modulant la vidange gastrique, probablement par l'intermédiaire de certaines hormones gastro-duodénales.

\section{References}

ALEXANDER D. P. NIXON D. A., 1969. Effect of parathyroid extract in foetal sheep. Biol. Neonate, $14,117-130$.

BARLET J. P., 1968. Effets de la thyrocalcitonine sur la calcémie ef la phosphatémie du veau. $C$. $R$. Acad. Sci., Paris, série D, 266, 395-398.

BARLET J. P., GAREL J. M., 1976. Effect of an intravenous injection of cholecystokinin-pancreozymin on plasma calcium and calcitonin levels in newborn lambs. J. Endocr., 70, 151-152.

BARLET J. P., GAREL J. M., LEFAIVRE J., DARDILLAT C., 1976. Régulation endocrinienne de la calcémie fotale chez la vache et la brebis. J. Physiol. Paris, 72, 34A.

BARLET J. P., MICHEL M. C., LARVOR P., THERIEZ M., 1971. Calcémie, phosphatémie, magnésémie ef glycémie comparées de la mère et du nouveau-né chez les ruminants domestiques (vache, chèvre, brebis). Ann. Biol. anim. Bioch. Biophys., 11, 415-426. 
BARLET J. P., MICHEL M. C., THERIEZ, M., SAVAJOL H., GAREL J. M., 1974 . Calcitoninémie et effets métaboliques de la calcitonine chez l'agneau nouveau-né. J. Physiol. Paris, 68, 519-529.

BAWDEN J. W.,WOLKOFF A. S., FLOWERS C. E., 1965. Maternal-fetal blood calcium relationships in sheep. Obstet. Gynecol., 25, 548-552.

BISHOP J. E., NORMAN A. W., 1975. Studies on calciferol metabolism. Metabolism of 25-hydroxyvitamin $D_{3}$ by the chicken embryo. Arch. Biochem. Biophys., 167, 769-773.

CARE A. D., BRUCE J. B., BOELKINS J., KENNY A. D., CONAWAY H., ANAST C. G., 1971. Role of pancreozymin-cholecystokinin and structurally related compounds as calcitonin secretagogues. Endocrinology, 89, 262-271.

CONELLY J. P., CRAWFORD J. D., WATSON J., 1962. Studies of neonatal hyperphosphatemia. Pediatrics, 30, 425-432.

CORRADINO R. A., TAYLOR A. N., WASSERMAN R. H., 1969. Appearance of vitamine $D_{3}$-induced calcium-binding protein (CaBP) in chick intestine during development. Fed. Proc., 28, 760.

CRAIG W. S., BUCHANAN M. F. G., 1958. Hypocalcaemic tetany developping within 36 hours of birth. Arch. Dis. Child., 33, 505-511.

DAVID L., ANAST C. S., 1974. Calcium metabolism in newborn infants. J. clin. Invest., 54, 287-296.

DELIVORIA-PAPADOPOULOS M., BATTAGLIA F. C., BRUNS P. D., MESCHIA G., 1967. Total, protein-bound and ultrafiltrable calcium in maternal and fetal plasmas. Am. J. Physiol., 213, 363-366.

FLEISCHMAN A. R., LERDAM S., OAKES G. D., EPSTEIN M. F., CHEZ R. A., MINTZ D. H., 1975. Perinatal primate parathyroid hormone metabolism. Biol. Neonate, 27, 40-49.

FRANKEL S., YASUMURA S., 1970. Intrathyroidal thyrocalcitonin levels in neonatal and adult rats. Endocrinology, 87, 602-605.

FREDERICH A., ROMAND-MONNIER M., LORAS B., DUMONT M., 1976. Variation saisonnière du taux de 25-hydroxycholécalciférol dans le sang du cordon de l'enfant nouveau-né. $C$. $R$. Acad. Sci., Paris, série D, 282, 2203-2206.

GAREL J. M., 1969a. Action hypocalcémiante et hypophosphatémiante de la thyrocalcitonine chez le rat avant et après la naissance. $C$. $R$. Acad. Sci., Paris série D, 268, 1525-1528.

GAREL J. M., 1969 b. Dosage biologique de la parathormone chez le jeune rat de 3 jours. C. $R$. Acad. Sci., Paris série D, 268, 2932-2933.

GAREL J. M., BARLET J. P., 1974. The effect of calcitonin and parathormone on plasma magnesium levels before and after birth in the rat. J. Endocr., 61, 1-13.

GAREL J. M., BARLET J. P., 1976. Calcium metabolism in newborn animals : the interrelationship of calcium, magnesium and inorganic phosphorus in newborn rats, foals, lambs and calves. Pediat. Res., 10, 749-754.

GAREL J. M., BARLET J. P., KERVRAN A., 1975. Metabolic effects of calcitonin in the newborn. Am. J. Physiol., 229, 669-675.

GAREL J. M., CARE A. D., BARLET J. P., 1974. A radioimmunoassay for ovine calcitonin : an evaluation of calcitonin secretion during gestation, lactation and foetal life. J. Endocr., 62, 497-509.

GAREL J. M., JULLIENNE A., 1977. Plasma calcitonin levels in pregnant and newborn rats. J. Endocr., 75, (in press).

GAREL J. M., MARTIN-ROSSET W., BARLET J. P., 1975. Plasma immunoreactive calcitonin levels in pregnant mares and newborn foals. Horm. Metab. Res., 7, 429-432.

GAREL J. M., SAVAJOL H., BARLET J. P., CARE A. D., 1973. Dosage radioimmunologique de la calcitonine chez le foetus de mouton. C. R. Acad. Sci., Paris série D, 277, 217-220.

GENGLER W. M., FORTE L. R., 1972. Neonatal development of rat kidney adenyl cyclase and phosphodiesterase. Biochim. biophys. Acta, 279, 367-372.

GIRARD J. R., FERRE P., PEGORIER J. P., 1976. Glucose homeostasis in the fasted newborn rats : role of lipids and gluconeogenic substrates. Diabetologia, 12, 393.

HADDAD J. G., BOISSEAU V., AVIOLI L. V., 1971. Placental transferof vitamin $D_{3}$ and 25-hydroxy cholecalciferol in the rat. J. Lob. clin. Med., 77, 908-915.

HESCH R. D., WOODHEAD S., HUEFNER M., WOLF H., 1973. Gastrointestinal stimulation of calcitonin in adults and newborns. Horm Metab. Res., 5, 235.

HILLMAN L. S., HADDAD J. G., 1974. Human perinatal vitamin D metabolism 1. 25 hydroxyvitamin $D$ in maternal and cord blood. J. Pediot., 84, 742-749. 
LARVOR P., BARLET J. P., 1968. Quelques aspects récents du métabolisme calcique : applications à la physiologie et à la pathologie des ruminants. Ann. Nutr. Alim., 22, 155-190.

LINARELLI L. G., 1972. Newborn urinary cyclic AMP and developmental renal responsiveness to parathyroid hormone. Pediatrics, 50, 14-23.

LINARELLI L. G., BOBIK J., BOBIK C., 1973. The effect of parathyroid hormone on rabbit renal cortex adenyl-cyclase during development. Pediat. Res., 7, 878-882.

MENDELSOHN M., HADDAD J. G., 1975. Postnatal fall and rise of circulating 25-hydroxyvitamin $D$ in the rat. J. Lab. clin. Med., 86, 32-37.

MILNER R. D. G., WOODHEAD J. S., 1975. Parathyroid hormone secretion during exchange transfusion. Arch. Dis. Child., 50, 298-303.

MORIUCHI S., DE LUCA H. F., 1974. Metabolism of vitamin $D_{3}$ in chick embryo. Arch. Biochem. Biophys., 164, 165-171.

PESHIN J., ORNOY A., MENCZEL J., 1976. Transplacental effect of thyrocalcitonin on intestinal calcium-binding protein, alkaline phosphatase activity and ossification of long bones in rat fetuses. Isr. J. med. Sci., 12, 248-256.

PHILLIPPO M., CARE A. D., HINDE F. R., 1969. The effect of thyrocalcitonin in neonatal animals. J. Endocr., 43, XV-XVI.

RADDE I. C., PARKINSON D. K., HOFFKEN B., 1971. lonized calcium in the healthy and diseased neonate. Proceed. XIII Int. Congr. Pediat., 363-365.

REYNOLDS J. J., HOLICK M. F., DE LUCA H., 1973. The role of vitamin D metabolites in bone resorption. Calcif. Tiss. Res., 12, 295-301.

ROSS R., CARE A. D., PICKARD D. W., REACOCK M., ROBINSON J. S., 1976. Plasma 25-hydroxyvitamin $D$ levels in the sheep foetus and neonate. J. Endocr., 71, $84 \mathrm{p}$.

SAMAAN N. A., ANDERSON G. D., ADAM-MAYNE M., 1975. Immunoreactive calcitonin in the mother, neonate, child and adult. Amer. Obstet. Gynecol., 121, 622-625.

SMITH F. G., TINGLOF B. O., MEULI J., BORDEN M., 1969. Fetal response to parathyroid hormone in sheep. J. appl. Physiol., 27, 276-279.

SMITH F. G., ALEXANDER D. P. BUCKLET R. M., BRITTON H. G., NIXON D. A., 1972. Parathyroid hormone in foetal and adult sheep : the effect of hypocalcemia. J. Endocr., 53, 339-348.

SWAMINATHAN R., BATES R. F. L., BLOOM S. R., GANGULI P. C., CARE A. D., 1973. The relationship between food, gastro-intestinal hormones and calcitonin secretion. J. Endocr., 59, 217-230.

TSANG R. C., CHEN I. W., FRIEDMAN M. A., CHEN I., 1973a. Neonatal parathyroid function : Role gestational age and postnatal age. J. Pediat., 83, 728-738.

TSANG R. C., LIGHT I. J., SUTHERLAND J. M., KLEINMAN L., 1973b. Possible pathogenetic factors in neonatal hypocalcemia of prematurity. J. Pediat., 82, 423.

TSANG R. C., KLEINMAN L. I., SUTHERLAND J. M., LIGHT I. J., 1972. Hypocalcemia in infants of diabetic mothers. J. Pediat., 80, 384-395.

TSANG R. G., CHEN I., HAYES W., ATKINSON W., ATHERTON H., EDWARDS N., 1974. Neonatal hypocalcemia in infants with birth asphyxia. J. Pediat., 84, 428-433.

VEGT G. B., De RUIJTER M., 1977 . The effect of $1 \alpha-25$ dihydroxycholecalciferol on uptake of calcium and incorporation of ${ }^{14} \mathrm{C}$-uridine and ${ }^{3} \mathrm{M}$-leucine in intestinal epithelial cells in vitro. Proc. kon. nederl. Akad. Wet., 80, 61.

WEISMAN Y., SAPIR R., HARELL A., EDELSTEIN S., 1976. Maternal-perinatal interrelationships of vitamin D metabolism in rats. Bioch. biophys. Acta, 428, 388-395.

YOUNG J. D., LAZARUS L., CHISHOLM D. J., ATKINSON F. F. U., 1969. Radioimmuno-assay of pancreozymin-cholecystokinin in human serum. J. nucl. Med., 10, 743-745. 